Discussion

Papers

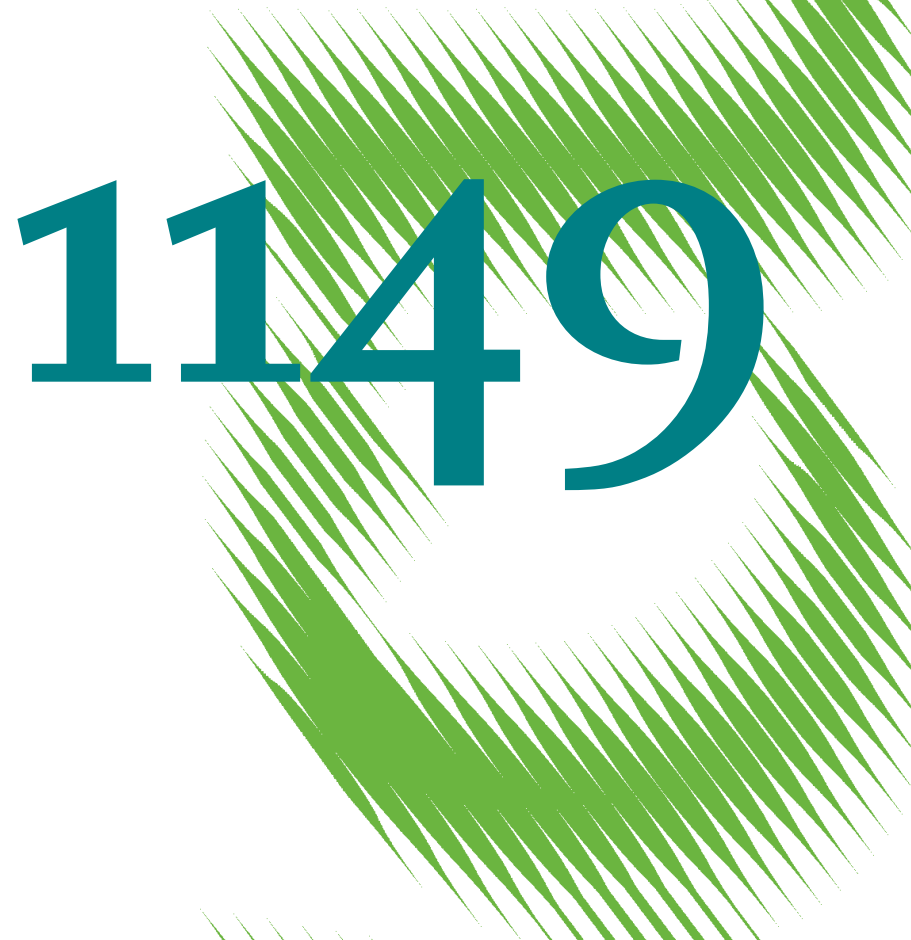

A Further Examination of the Export-Led Growth Hypothesis 
Opinions expressed in this paper are those of the author(s) and do not necessarily reflect views of the institute.

IMPRESSUM

(C) DIW Berlin, 2011

DIW Berlin

German Institute for Economic Research

Mohrenstr. 58

10117 Berlin

Tel. $+49(30) 89789-0$

Fax +49 (30) $89789-200$

http://www.diw.de

ISSN print edition $1433-0210$

ISSN electronic edition 1619-4535

Papers can be downloaded free of charge from the DIW Berlin website:

http://www.diw.de/discussionpapers

Discussion Papers of DIW Berlin are indexed in RePEc and SSRN:

http://ideas.repec.org/s/diw/diwwpp.html

http://www.ssrn.com/link/DIW-Berlin-German-Inst-Econ-Res.html 


\title{
A further examination of the export-led growth hypothesis
}

\author{
Christian Dreger
}

Dierk Herzer ${ }^{1}$

\begin{abstract}
This paper challenges the common view that exports generally contribute more to GDP growth than a pure change in export volume, as the export-led growth hypothesis predicts. Applying panel cointegration techniques to a production function with non-export GDP as the dependent variable, we find for a sample of 45 developing countries that: (i) exports have a positive short-run effect on non-export GDP and vice versa (short-run bidirectional causality), (ii) the long-run effect of exports on nonexport output, however, is negative on average, but (iii) there are large differences in the long-run effect of exports on non-export GDP across countries. Cross-sectional regressions indicate that these cross-country differences in the long-run effect of exports on non-export GDP are significantly negatively related to cross-country differences in primary export dependence and business and labor market regulation. In contrast, there is no significant association between the growth effect of exports and the capacity of a country to absorb new knowledge.
\end{abstract}

Keywords Export-led growth · Developing countries · Panel cointegration

JEL-Classification $\quad \mathrm{F} 43 \cdot \mathrm{O} 11 \cdot \mathrm{C} 23$

1 Dreger: German Institute for Economic Research (DIW Berlin) and European University Frankfurt (Oder), email: cdreger@diw.de, Herzer (corresponding author): Department of Economics, HelmutSchmidt-University, Holstenhofweg 85, D-22043 Hamburg, e-mail: herzer@hsu-hh.de. 



\section{$1 \quad$ Introduction}

The question of whether exports are a key factor in promoting growth in developing countries, as stated by the export-led growth hypothesis, has been the subject of numerous studies over the past decades. These studies can be divided into four groups. ${ }^{2}$ The first includes cross-country studies, such as Michaely (1977), Balassa (1978), Heller and Porter (1978), Tyler (1981), Feder (1983), Kavoussi (1984), Ram (1985), and McNab and Moore (1998). Collectively, this series of studies supports a positive association between export growth and output growth in developing countries. However, they assume, rather than demonstrate, that export growth has a positive causal effect on GDP (or GNP) growth, thus ignoring the fact that a positive correlation between these two variables can also be compatible with causality running from output growth to export growth. Furthermore, the estimates in these studies may be biased if causality runs in both directions. In addition, country-specific factors may cause apparent differences in the effect of exports on growth across countries, but these factors cannot be fully controlled for in cross-country regressions. This gives rise to the classical omitted-variables problem.

In response to these criticisms, the second group of studies investigates the causal relationship between export growth and output growth for individual countries using Granger's (1969) or Sims' (1972) causality test. ${ }^{3}$ Among these studies are Jung and Marshall (1985), Chow (1987), Hsiao (1987), Bahmani-Oskooee et al. (1991), Dodaro (1993), Sharma and Dhakal (1994), Love (1994), and Riezman et al. (1996). Overall, these authors suggest that export growth has no causal effect on output growth in the

\footnotetext{
${ }^{2}$ For comprehensive reviews of the literature, see Edwards (1993) and Giles and Williams (2000).
} 
majority of developing countries. However, they do not examine whether exports and GDP are cointegrated. Specifically, most of these studies test for causality by employing simple VAR models in growth rates or first differences. It is well known that the use of stationary first differences (or growth rates) avoids possible spurious correlations, but this approach precludes the possibility of a long-run or cointegrating relationship between the level of exports and the level of output a priori. Moreover, using first differences may lead to misspecification bias if a long-run or cointegrating relationship between the levels of the variables exists (Granger 1988). Indeed, there are some studies that estimate VAR models of the (log) level of exports and the (log) level of GDP. However, standard F-tests for Granger causality based on VAR models in levels are not valid if the underlying variables are nonstationary and not cointegrated (Toda and Phillips 1993).

In light of these limitations, the third group of studies uses cointegration techniques to examine the long-run relationship between exports and output for individual countries. This group includes, for example, Bahmani-Oskooee and Alse (1993), Van den Berg and Schmidt (1994), Ahmad and Harnhirun (1995), Al-Yousif (1997), AbuQarn and Abu-Bader (2004), Love and Chandra (2004), Bahmani-Oskooee and Oyolola (2007), and Bahmani-Oskooee and Economidou (2009). Taken as a whole, these studies suggest that in most developing countries there is a positive long-run relationship between exports and output, and that causality is running from exports to output or in both directions. A limitation of these studies, however, is the low power of the tests due to the small sample size associated with the use of individual country time-series data.

\footnotetext{
${ }^{3}$ It should be noted that another group of studies uses time-series regressions estimated by OLS. This group includes, for example, Ram (1987), Salvatore and Hatcher (1991), Greenaway and Sapsford (1994). Like the cross-country studies, these papers do not test the direction of causality.
} 
Therefore, the fourth group of studies employs panel cointegration methods to examine the export-led growth hypothesis. Panel tests have higher power due to the exploitation of both the time-series and cross-sectional dimensions of the data. To our knowledge, this group includes only four studies and the results are mixed. While Bahmani-Oskooee et al. (2005) and Reppas and Christopoulos (2005) conclude that longrun causality is unidirectional from GDP to exports, the results of Parida and Sahoo (2007) suggest that increased exports are a cause of increased GDP; Jun (2007), on the other hand, finds support for positive long-run effects running from exports to GDP and vice versa. However, these studies also have limitations.

Reppas and Christopoulos (2005) and Parida and Sahoo (2007) consider only a relatively small number of countries. More specifically, Reppas and Christopoulos analyze a sample of 22 African and Asian countries, while the sample of Parida and Sahoo includes only four South Asian countries. Thus, it is questionable whether the results are representative for the group of developing countries as a whole. Another limitation is that Parida and Sahoo (2007) and Jun (2007) use within-dimension panel cointegration estimators, which, by construction, are unable to capture the heterogeneity of the longrun coefficients across countries. Hence, these studies do not allow conclusions regarding the long-run effects of exports (and thus the validity of the export-led growth hypothesis) for individual countries. Furthermore, the methods used in these studies do not take account of potential cross-sectional dependence, which could have biased the results. ${ }^{4}$ In addition, and perhaps most importantly, Bahmani-Oskooee et al. (2005), Reppas and Christopoulos (2005), Jun (2007), and numerous other studies do not control for

\footnotetext{
${ }^{4}$ Cross sectional dependence can arise due to several factors, such as omitted observed or unobserved common factors, or spatial spillover effects. For example, the data may be in part driven by common global business cycles.
} 
the simultaneity bias associated with the fact that exports, via the national income accounting identity, are themselves a component of GDP. Specifically, the problem is that a positive correlation may emerge simply because exports are part of GDP (rather than because of any extra contribution that exports make to GDP or, conversely, because of any extra contribution that GDP makes to exports), and that this simultaneity between exports and output may also lead to potentially misleading inferences on causality. Finally, a common feature of these cointegration studies is that they examine only the long-run relationship between exports and output and thus do not account for possible differences between the long-run and short-run effects of exports.

This paper contributes to the literature in several ways. First, panel cointegration techniques are applied to investigate the export led-growth hypothesis for 45 developing countries, both for the sample as a whole and for each country individually. In contrast to previous panel cointegration studies, we use so called second-generation panel unit root and cointegration methods to take the potential cross-sectional dependence into account. More specifically, unit roots and cointegration are tested for common and idiosyncratic components. Second, we use non-export GDP instead of export-inclusive GDP to separate the influence of exports on output from that incorporated in the 'growth-accounting' relationship. Third, we examine both the long-run and short-run effects of exports on non-export GDP to obtain insights into the dynamics of exports over time.

Our main findings are as follows: (i) Exports exert a positive short-run effect on non-export GDP in developing countries and vice versa (short-run bidirectional causality), (ii) the long-run effect of exports on non-export output, in contrast, is negative on 
average, and (iii) there are large differences in the long-run effect of exports on nonexport GDP across countries.

Given this latter finding, it is natural to ask how these differences can be explained. As a further contribution, we attempt to answer this question by examining whether the observed cross-country differences in the long-run effects of exports are linked to country-specific factors, such as the level of primary export dependence, business regulation, labor regulation, and the capacity to absorb foreign knowledge. Using cross-sectional regression analysis, we find that the cross-country differences in the long-run effects of exports on non-export GDP are significantly negatively related to cross-country differences in primary export dependence, business regulation, and labor regulation, whereas there is no statistically significant association between the growth effect of exports and absorptive capacity. Although caution is needed in drawing policy conclusions, we think that this is an important finding for countries which pursue export-oriented development strategies.

The rest of the paper is organized as follows. Section 2 discusses the export-led growth hypothesis in more detail and sets out the empirical model. Section 3 describes the data and presents the econometric methodology. The empirical results are reported in Section 4 and Section 5 provides some concluding remarks.

\section{Export-led growth hypothesis}

\subsection{Theoretical discussion}

It is conventional wisdom among policy makers and academics that exports are a key factor in promoting economic growth in developing countries; there are several theo- 
retical arguments supporting this hypothesis. From a demand-side perspective, it is argued that sustained growth cannot be maintained in domestic markets because of their limited size. Export markets, in contrast, are almost limitless and hence do not involve growth restrictions on the demand side, implying that they can act as a catalyst for output growth through an expansion of aggregate demand (Siliverstovs and Herzer 2007). This is the direct and intuitively obvious growth effect of exports that does not need to be investigated further. Given the fact that the export-to-GDP ratio in developing countries increased from about 10 percent in 1970 to about 35 percent in 2006, it immediately becomes clear that exports have played a major role in the growth process of developing countries, as part of domestic production demanded by foreign buyers. In the empirical analysis, however, this direct effect must be controlled for. The reason is that the export-led growth hypothesis, in its original form, predicts that exports have an indirect growth effect that goes beyond the mere change in export volume: an effect on output through productivity.

There are several ways in which exports can affect productivity. First, exports can provide the foreign exchange to finance imports that incorporate knowledge of foreign technology and production know-how, thereby promoting cross-border knowledge spillovers (Grossman and Helpman 1991). Second, exports can increase productivity by concentrating investment in the most efficient sectors of an economy, those in which the country has a comparative advantage (Kunst and Marin 1989). Third, since combining the international market with the domestic market facilitates larger-scale operations than does the domestic market alone, an expansion of exports allows countries to benefit from economies of scale (Helpman and Krugman 1985). Fourth, and perhaps most importantly, the export sector may generate positive externalities on the non-export sector 
(Feder 1983). The sources of these knowledge spillovers include, on the one hand, incentives for technological improvements, labor training, and more efficient management due to increased international competition and, on the other, direct access to foreign knowledge through relationships with foreign buyers (Chuang 1998).

Several arguments suggest, however, that the positive productivity effects predicted by the export-led growth hypothesis do not necessarily occur in developing countries. One concern is that many developing countries are heavily dependent on primary commodity exports. Such exports can lead economies to shift away from competitive manufacturing sectors in which many externalities required for sustainable growth are generated, while the primary export sector itself does not (by its nature) have many linkages with, and spillovers into, the economy (Sachs and Warner 1995; Herzer 2007). Furthermore, exports of primary goods tend to be subject to large price and volume fluctuations. Increased exports may therefore lead to increased macroeconomic uncertainty, which, in turn, may hamper efforts for economic planning and reduce the quantity as well as the efficiency of domestic investment (Dawe 1996).

Another concern is that the ability of the non-export sector to absorb potential knowledge spillovers from the export sector depends on its absorptive capacity. In particular, domestically oriented firms using very backward production technology and low-skilled workers may be unable to make effective use of knowledge spillovers. Similarly, it can be argued that a certain level of technology and human capital in the export sector itself may be necessary to acquire foreign technology (Edwards 1993).

Finally, many developing countries are subject to excessive business and labor regulations that limit both the mobility of factors between sectors and the flexibility of factor prices (World Bank 2009). In such a scenario of severe factor-market imperfec- 
tions, an increase in exports may be associated with un- or underemployment and, as a consequence, with productivity losses (Edwards 1988).

From this discussion, it follows that the productivity effects of exports are ambiguous and depend upon several factors, such as the level of primary export dependence, the degree of absorptive capacity, and the degree of business and labor regulations. A simple but important implication of this is that the effects of exports on output through productivity may differ significantly from country to country. Another implication of the above discussion is that the productivity effects of exports may differ over time, as well. For example, in the short run, exports may increase productivity through specialization according to comparative advantage. If, however, the increase in exports induces an expansion of sectors that do not exhibit positive externalities while other sectors with positive externalities shrink, the associated productivity loss will more than offset the traditional static specialization gains in the long run. Accordingly, exports may have positive short-run, but negative long-run effects.

\subsection{Empirical specification}

In order to capture the impact of exports on output through the productivity channel, we start with an $A K$-type production function:

$$
Y_{i t}=A_{i t} K_{i t}{ }^{b_{1 i}} \text {, }
$$

where $Y_{i t}$ is the output of country $i$ at time $t, K_{i t}$ is the capital of country $i$ at time $t$, and $A_{i t}$ is a productivity parameter. Because we want to examine if and how exports affect 
economic growth via changes in productivity, it is assumed that the productivity parameter can be expressed as a function of exports, $X_{i t}$,

$$
A_{i t}=f\left(X_{i t}\right)=X_{i t}^{b_{2 i}}
$$

Combining Eq. (1) and Eq. (2) and taking natural logarithms yields

$$
\ln \left(Y_{i t}\right)=b_{1 i} \ln \left(K_{i t}\right)+b_{2 i} \ln \left(X_{i t}\right),
$$

where the coefficients $b_{1 i}$ and $b_{2 i}$ denote the cross-country averages of the elasticities of output with respect to capital and exports, which are allowed to be country specific and thus to vary across countries.

However, the estimate of $b_{2 i}$ cannot be used to measure the average productivity effect of exports on output. Since exports are a part of output via the national accounting identity, a positive and significant relationship between exports and output is almost inevitable, even if there are no productivity effects. To remedy this problem, we separate the impact of exports on output from that incorporated through the national accounts identity, by considering real output net of exports, $N_{i t}=Y_{i t}-X_{i t}$ (e.g., Greenaway and Sapsford 1994; Siliverstovs and Herzer 2007). By replacing the logarithm of total output, $\ln \left(Y_{i t}\right)$, with the logarithm of non-export output, $\ln \left(N_{i t}\right)$, we obtain

$$
\ln \left(N_{i t}\right)=c_{1 i} \ln \left(K_{i t}\right)+c_{2 i} \ln \left(X_{i t}\right) .
$$

The coefficient $c_{2 i}$ in this equation is $0, c_{2 i}=0$, if the coefficient of the export variable in the augmented production function specification, indicated by Eq. (3), just reflects 
the share of exports in output. ${ }^{5}$ If, in contrast, the coefficient $c_{2 i}$ is greater than 0 , $c_{2 i}>0$, the growth effect of exports goes beyond the mere increase in export volume, suggesting that exports increase output through increased productivity; whereas if $c_{2 i}<0$, exports contribute less to GDP growth than the increase in export volume, suggesting that exports are productivity-reducing (Siliverstovs and Herzer 2007).

To control for country-specific omitted factors that are relatively stable or evolve smoothly over time, we include country-specific fixed effects, $c_{3 i}$, and country-specific deterministic time trends, $c_{4 i} t$. While country fixed effects control for unobserved timeconstant heterogeneity, country-specific time trends capture any unobserved factors that change gradually over time. Because reliable employment data are not available for many developing countries over a long enough time span and because several studies suggest that hours worked are stationary around a time trend (e.g., DeJong and Whiteman 1991; Leybourne 1995; Banerjee and Russel 2005), country-specific time trends can act, for example, as a proxy for labor input. Adding the error term, $\varepsilon_{i t}$, yields the following regression model:

$$
\ln \left(N_{i t}\right)=c_{1 i} \ln \left(K_{i t}\right)+c_{2 i} \ln \left(X_{i t}\right)+c_{3 i}+c_{4 i} t+\varepsilon_{i t} .
$$

Unlike other studies, we do not include imports, given the discussion in the previous subsection. If we included imports, the estimate of the effect of exports on output through productivity would preclude any effect operating through the import channel. Specifically, if export earnings are used to finance imports, then, by including imports

\footnotetext{
${ }^{5}$ A multiplicative relationship of the form: $Y=X^{\alpha} N^{1-\alpha}$ is assumed, where $a$ is the share of exports in GDP (for convenience the subscript $i$ is omitted). Inserting this equation into Eq. (3) yields after some manipulations Eq. (4), with $c_{1}=b_{1} /(1-\alpha), c_{2}=\left(b_{2}-\alpha\right) /(1-\alpha)$. Thus, if $b_{2}=\alpha$, then $c_{2}=0$.
} 
in the regression, we would be omitting the productivity effect of exports that operates via imports.

\section{$3 \quad$ Data and empirical methodology}

\subsection{Data}

The data are from the World Development Indicators (2008). Exports $\left(X_{i t}\right)$ include both goods and services; gross capital formation is our proxy for capital $\left(K_{i t}\right)$; and the non-export output $\left(N_{i t}\right)$ is measured by GDP minus exports of goods and services. All data are in constant 2000 dollars; our sample includes all countries for which continuous data are available from 1971 to 2005. Of these countries, four are in North Africa (Algeria, Egypt, Morocco, and Tunisia), nineteen are in sub-Saharan Africa (Benin, Burkina Faso, Cameroon, Côte d'Ivoire, Gambia, Ghana, Guinea-Bissau, Kenya, Lesotho, Madagascar, Malawi, Mali, Rwanda, Senegal, South Africa, Sudan, Swaziland, Togo, and Zambia), nine are in South America (Argentina, Bolivia, Brazil, Chile, Colombia, Ecuador, Paraguay, Peru, and Uruguay), six are in Central America and the Caribbean (Costa Rica, Dominican Republic, El Salvador, Guatemala, Honduras, and Mexico), three are in East Asia (Indonesia, Thailand, and South Korea), and four are in South Asia (Bangladesh, India, Iran, and Pakistan).

\subsection{Empirical methodology}

Since all variables are integrated of order one (as shown in Section 4), our analysis is based on the cointegration approach. However, standard time series unit root and coin- 
tegration tests have low power against stationary alternatives in small samples (Campbell and Perron 1991). Panel tests make progress in this respect. Since panel tests exploit both the time series and cross-sectional dimension of the data, they are more powerful than conventional time series unit root and cointegration tests.

However, these tests have their own problems. Standard panel unit root and cointegration tests are based on the assumption of cross-sectional independence. Due to common shocks, this assumption is often violated in practice. The problem is that crosssectional dependence can lead to severe size distortions, as shown by Banerjee et al. (2005) among others. The test statistics are not normally distributed and the usual critical values do not apply; the situation gets even worse when the number of cross sections is increased. To overcome this deficit, recent panel unit root and cointegration tests allow for cross-sectional dependence via common factors.

In fact, the cointegration property might be interpreted in different ways. A longrun relationship may exist between the cross sections and between the time series for single units in the panel. Gengenbach et al. (2006) have proposed a sequential testing strategy. They examine the case where nonstationarities are driven by a reduced number of common stochastic trends, and the case where both common and idiosyncratic stochastic trends are present in the data.

The starting point is a decomposition of each variable into common factors and idiosyncratic parts, as suggested by Bai and $\mathrm{Ng}$ (2004). If the common factors are integrated of order one, $I(1)$, but the idiosyncratic components are $I(0)$, the nonstationarity in the panel would be driven entirely by a reduced number of global stochastic trends. This applies to the case of cross section cointegration. Such cointegration between the series occurs only if the common factors of the variables cointegrate. If both the com- 
mon factors and the idiosyncratic components are $I(1)$, cointegration is explored separately for the common and idiosyncratic components. Cointegration requires that the null hypothesis of no cointegration is rejected for both the common and the idiosyncratic components.

The presence of a cointegrating relationship between the common factors can be tested using standard time-series cointegration tests such as the Johansen (1995) reduced rank approach. Since the idiosyncratic components are independent by construction, they can be analyzed by standard panel cointegration tests such as those of Pedroni $(1999,2004)$.

Once it is established that the variables are cointegrated, the next step is to estimate the parameters of the cointegrating equation (Eq. (5)). To this end, we use the between-dimension group-mean panel DOLS estimator that Pedroni (2001) argues has a number of advantages over the within-dimension approach. First, it allows for greater flexibility in the presence of heterogeneous cointegrating vectors, whereas under the within-dimension approach the cointegrating vectors are constrained to be the same for each country. Second, the point estimates provide a more useful interpretation in the case of heterogeneous cointegrating vectors, as they can be interpreted as the mean value of the cointegrating vectors, which does not apply to the within estimators. Third, between-dimension estimators suffer from much lower small-sample size distortions than is the case with the within-dimension estimators. The panel DOLS regression is given by

$$
\begin{aligned}
\ln \left(N_{i t}\right) & =c_{1 i} \ln \left(K_{i t}\right)+c_{2 i} \ln \left(X_{i t}\right)+c_{3 i}+c_{4 i} t \\
& +\sum_{j=-k_{i}}^{m_{i}} \Phi_{1 i j} \Delta \ln \left(K_{i t-j}\right)+\sum_{j=-l_{i}}^{n_{i}} \Phi_{2 i j} \Delta \ln \left(X_{i t-j}\right)+\varepsilon_{i t}
\end{aligned}
$$


where $\Phi_{1 i j}$ and $\Phi_{2 i j}$ are coefficients of lead and lag differences. The leads and lags account for possible serial correlation and endogeneity of the regressors, implying that the DOLS procedure generates unbiased estimators for variables that cointegrate even with endogenous regressors. In addition, the group-mean panel DOLS estimator is superconsistent under cointegration, and is robust to the omission of variables that do not form part of the cointegrating relationship. It is calculated as $\hat{c}_{m}=N^{-1} \sum_{i=1}^{N} \hat{c}_{i}$, where $t_{\hat{c}_{m}}=\sum_{i=1}^{N} t_{\hat{c}_{i}} / \sqrt{N}$ is the corresponding $t$-statistic of $\hat{c}_{m}(m=1,2)$, and $\hat{c}_{m i}$ is the conventional time-series DOLS estimator applied to the ith country of the panel. According to Stock and Watson (1993), this estimator performs well in small samples (like ours) compared with other cointegration estimators, such as the maximum likelihood estimator of Johansen (1988) or the fully modified ordinary least squares estimator of Phillips and Hansen (1990).

Finally, to test the direction of causality and to examine the short-run dynamics between the variables (in particular between exports and non-export GDP), we estimate a panel vector error-correction model given by

$$
\left[\begin{array}{c}
\Delta \ln \left(N_{i t}\right) \\
\Delta \ln \left(K_{i t}\right) \\
\Delta \ln \left(X_{i t}\right)
\end{array}\right]=\left[\begin{array}{l}
\mu_{1 i} \\
\mu_{2 i} \\
\mu_{3 i}
\end{array}\right]+\sum_{j=1}^{p} \Gamma_{j}\left[\begin{array}{l}
\Delta \ln \left(N_{i t-j}\right) \\
\Delta \ln \left(K_{i t-j}\right) \\
\Delta \ln \left(X_{i t-j}\right)
\end{array}\right]+\left[\begin{array}{l}
a_{1} \\
a_{2} \\
a_{3}
\end{array}\right] e c_{i t-1}+\left[\begin{array}{c}
\varepsilon_{1 i t} \\
\varepsilon_{2 i t} \\
\varepsilon_{3 i t}
\end{array}\right],
$$

where $\mu_{1 i}, \mu_{2 i}$, and $\mu_{3 i}$ are fixed effects, the lagged differenced variables represent the short-run dynamics, and the error correction term, $e c_{i t}$, is the residual from the estimated DOLS long-run relationships of the individual countries: 


$$
e c_{i t}=\ln (N)_{i t}-\left[\hat{c}_{1 i} \ln \left(K_{i t}\right)+\hat{c}_{2 i} \ln \left(X_{i t}\right)+\hat{c}_{3 i}+\hat{c}_{4 i} t\right]
$$

If the coefficient on $e c_{i t-1}\left(a_{1}, a_{2}, a_{3}\right)$ is significant, the null hypothesis of weak exogeneity is rejected, implying long-run Granger causality from the regressors to the dependent variable(s) (see, e.g., Granger 1988). The short-run causal effects are captured by the short-run dynamics.

\section{$4 \quad$ Empirical results}

This section is devoted to the empirical analysis of the export-led growth hypothesis. Specifically, we examine the following questions:

1. Is there a long-run relationship between non-export GDP, capital, and exports?

2. If yes, how do exports affect non-export GDP in the long run, and how is nonexport GDP affected by exports in the short run?

3. Are there significant differences in the long-run effects of exports on non-export GDP across countries?

4. If yes, can these differences be explained by cross-country differences in primary export dependence, absorptive capacity, and business and labor regulations, as hypothesized in Section 2?

\subsection{Unit Roots and cointegration}

The first step of the analysis is to investigate the integration and cointegration properties of the variables. To allow for cross-unit cointegration, we test for unit roots and cointe- 
gration in the common and idiosyncratic components of the data (instead of the observed series). ${ }^{6}$ The common and idiosyncratic components of the series are estimated using the principle component estimator of Bai and $\mathrm{Ng}$ (2004). Because the components can be nonstationary, the principal components are extracted from the differenced data, as suggested by Bai and $\mathrm{Ng}$ (2004). Once the factors have been estimated, they are recumulated to match the stochastic properties of the original series. The idiosyncratic components are computed as the projections of the observations onto their common components.

\section{- Table 1 about here -}

The number of common factors is estimated using the BIC3 criterion of Bai and $\mathrm{Ng}$ (2002). Since the cross-section and time-series dimensions of the panel are of similar magnitude, the BIC3 criterion may be superior to alternatives. However, this criterion does not converge in the present application, since a large number of factors is preferred. Therefore, the best strategy is to look at different settings to ensure the robustness of the analysis. The evidence presented below refers to six principal components per variable. To arrive at the common factors, they are weighted by their corresponding eigenvalues. The factors represent 50 percent of the overall variation of the respective series. Fortunately, the results are very robust to this choice. ${ }^{7}$ While the common factors appear to be nonstationary, the unit root hypothesis is rejected for the idiosyncratic components of the variables, as Table 1 shows. Thus, the variables can become cointe-

\footnotetext{
${ }^{6}$ We also tested for cointegration between the observed series (without allowing for cross-unit cointegration) and found strong evidence for cointegration. The results are reported in an earlier version of this paper (see Herzer 2010).
} 
grated for the individual countries of the panel via the common nonstationary factors. In fact, the Johansen (1995) trace statistics reported in Table 2 indicate that the common factors of $\ln \left(N_{i t}\right), \ln \left(K_{i t}\right)$, and $\ln \left(X_{i t}\right)$ are cointegrated and exhibit a single cointegrating vector. Regarding the idiosyncratic components, the Pedroni $(1999,2004)$ statistics also provide evidence for cointegration (see Table 3). Admittedly, the Pedroni test does not provide further insight, since all variables are stationary in this case. Therefore, they should be regarded as a cross check.

\section{- Tables 2 and 3 about here -}

\subsection{Long-run elasticities}

The DOLS group-mean estimates of the coefficients on capital and exports are reported in the first row of Table $4 .{ }^{8}$ The results are based on a one lead/lag model, as suggested by the usual information criteria. The coefficient on $\ln \left(K_{i t}\right)$ is highly significant and positive, as expected. The coefficient of the export variable, in contrast, is highly significant and negative. More precisely, the coefficient on $\ln \left(X_{i t}\right)$ is estimated to be -0.152 , implying that, in the long-run, a one percent increase in exports leads to a 0.152 percent decrease in non-export GDP on average for the countries in our sample.

Since this finding challenges the conventional view that exports generally contribute more to GDP growth than the mere change in export volume, we perform several

\footnotetext{
7 The results can be replicated, if the common factors are obtained as a combination of the first three, four, five or even seven principal components of the variables. Results are available from the authors upon request.

${ }^{8}$ Since the focus of our interest later in this paper will be on examining the cross-country heterogeneity in the long-run effects of exports on non-export GDP, the average long-run relationship is estimated using the original series (consisting of nonstationary common and stationary idiosyncratic components). The capital and export elasticities from the Johansen estimator for the common components are respectively 1.090 and -0.233 . Thus, consistent with the estimation results in Table 4, the Johansen estimator produces a negative coefficient on the export variable for the common components.
} 
sensitivity checks. First, we re-estimate the group-mean panel DOLS regression using two leads and lags. The results are reported in the second row of Table 4 . They are very similar to those in row 1 . Thus, the estimates appear to be not sensitive to the choice of the lead and lag length (although the usual information criteria select one lead/lag model).

- Table 4 about here -

Next, we examine whether the negative long-run relationship between exports and non-export output is robust to alternative estimation techniques. Specifically, we use the within-dimension DOLS estimator suggested by Kao and Chiang (2000), which differs from the between-dimension group-mean DOLS estimator in that it assumes homogeneous long-run coefficients $\left(c_{1}\right.$ and $\left.c_{2}\right)$ for all countries.

Because, however, the DOLS estimates could be biased in the presence of crosssectional dependence, we also report (in the third row) the result of the common correlated effects (CCE) mean group estimator suggested by Pesaran (2006). Compared to the use of common time dummies (to control for cross-sectional dependence through common time effects), as is common practice in panel studies, the CCE mean group estimator has the advantage that it allows for cross-sectional dependencies arising from multiple unobserved common factors, and that it permits the individual responses to the common factors to differ across countries. It augments the cointegrating regression (given by Eq. (5)) with the cross-sectional averages of the dependent variable and the observed regressors as proxies for the unobserved factors. Kapetanios et al. (2011) have 
recently shown that the CCE estimator is consistent regardless of whether the common factors are stationary or nonstationary.

As can be seen, all three estimators provide qualitatively similar results. As expected, the within-dimension estimator tends to produce somewhat lower estimates (in absolute value) than the group-mean estimator, which is in line with the findings of Pedroni (2001). Given, however, that the effects of exports on non-export GDP differ across countries (as demonstrated in Subsection 4.4), the results of the pooled withindimension estimator (which assumes homogeneous coefficients) should be interpreted with caution. The CCE mean group estimator, on the other hand, is intended for the case in which the regressors are exogenous, so that we lose the ability to account for the potential endogeneity of exports. Therefore, we continue our robustness analysis with the group-mean panel DOLS estimator.

- Figure 1 about here -

We examine whether the negative effect of exports and non-export GDP is the result of outliers. To this end, we reestimate the group-mean DOLS regression excluding one country at a time from the sample. The sequentially estimated export coefficients and their $t$-statistics are presented in Figure 1. Since the coefficients are fairly stable around -0.15 and always significant at one percent level, we conclude that the results are not driven by outliers.

We also examine whether the negative long-run relationship between exports and non-export output in developing countries is due to sample-selection bias. Specifically, a group of countries in a particular region could have a significant effect on the 
results. To investigate this issue, we reestimate Eq. (6), excluding countries from North Africa, sub-Saharan Africa, South America, Central America and the Caribbean, East Asia, and South Asia. The resulting group-mean values for $c_{2}$ are reported in Table 3. Regardless which of these regions is excluded from the sample, the long-run relationship between exports and non-export GDP remains negative and highly significant.

\section{- Tables 5 and 6 about here -}

Finally, we check whether the results are sensitive to the sample period. For this purpose, we reestimate the DOLS regression for two non-overlapping subperiods of equal length from 1971 through 1987 and 1988 through 2004. The results are presented in Table 4. Once again, the estimated effect of exports is negative and statistically significant (although there is some variation in the coefficients). Thus, it can be concluded that the negative long-run effect of exports on non-export GDP in developing countries is robust to different estimation techniques, outliers, sample selection, and the sample period.

\subsection{Short-run and long-run causality}

The above interpretation of the estimation results is based on the assumption that longrun causality runs from capital and exports to GDP net of exports. In order to test this assumption, we use a panel vector error correction as given by Eq. (7). Following Herzer (2008), we begin with an overparameterized model. We then eliminate the insignificant short-run dynamics in the model successively according to the lowest $t$-values until 
the remaining variables are significant at least at the 5\% level. The results are reported in Table 7.

- Table 7 about here -

According to the $t$-statistics of the error-correction terms, capital and exports can be regarded as weakly exogenous with respect to the cointegrating relationship, whereas the weak exogeneity hypothesis of GDP net of exports is decisively rejected. Thus, only non-export GDP reacts to deviations from the long-run equilibrium relationship, implying that long-run causality runs unidirectional from capital and exports to non-export GDP.

Another important result is that the coefficient on $\Delta \ln \left(X_{i t-1}\right)$ is statistically significant and positive in column 2 , while the coefficient on $\Delta \ln \left(N_{i t-1}\right)$ is statistically significant and positive in column 4 . Thus, there is evidence of short-run bidirectional causality between exports and non-export GDP, suggesting that, in the short-run, export growth leads to non-export GDP growth, which in turn leads to an increase in exports. As noted in Section 2, a possible explanation for the positive short-run effect of exports is static specialization gains, whereas, in the long run, the negative dynamic effects of exports on non-export GDP, possibly associated with primary export dependence and/or excessive business and labor regulations, tend to offset the short-run gains.

There is also evidence of short-run causality from exports to capital and vice versa; the first difference of exports, lagged one period, is significant and positive in the capital equation in column 3 , while the coefficients on $\Delta \ln \left(K_{i t-1}\right)$ and $\Delta \ln \left(K_{i t-2}\right)$, in turn, are statistically significant and positive in the export equation in Column 4 . From 
this it can be concluded that, in the short run, increased exports are both a cause and a consequence of increased investment.

Summarizing, we find that the short-run relationship between exports and nonexport GDP is positive, whereas the long-run effect of exports on non-export GDP is clearly negative. This result for the sample as a whole does, however, not imply that exports exert a negative long-run effect on non-export GDP in each individual country.

\subsection{Individual country effects}

Figure 2 plots the individual country DOLS estimates of the coefficients on $\ln \left(X_{i t}\right), \hat{c}_{2 i}$. The most striking feature of these estimates is the heterogeneity in the coefficients, ranging from -0.774 in Gambia to 0.555 in Brazil. Thus, although the long-run effect of exports on non-export GDP is negative in general or on average in developing countries, exports do not have a negative long-run effect on non-export GDP in all countries. More precisely, we find for 31 out of 44 countries (and thus in 69 percent of cases) that an increase in exports is associated with a decrease in non-export GDP, while in 14 cases (and thus in 31 percent of the countries) an increase in exports is associated with an increase in non-export GDP. But even within the country groups with negative and positive effects, the individual country estimates show considerable heterogeneity. For example, the point estimates suggest that Brazil, Honduras, Swaziland, and Malawi benefit markedly from exports. In contrast, in many countries, such as Columbia, Egypt, El Salvador, and India, both the positive and negative effects are marginal (close to 0), whereas in many other countries, such as Gambia, Cote d'Ivoire, Thailand, and Indonesia exports have a strong negative effect on non-export GDP. Of course, the estimates of 
the coefficient on $\ln \left(X_{i t}\right)$ from the group-mean panel DOLS estimator must be interpreted with caution given the relatively short sample period. Moreover, it should be noted that not all coefficients are significant in statistic terms. ${ }^{9}$

\section{- Figure 2 about here -}

4.5 Explaining cross-country differences in the long-run impact of exports on nonexport GDP

The cross-country differences in the long-run effect of exports on non-export GDP pose a new question: What factors can explain this heterogeneity or, in other words, what factors determine the long-run effect of exports on non-export GDP? Following the arguments of Section 2, a possible way to answer this question is to examine whether the observed pattern of the long-run effects of exports can be linked to cross-country differences in the level of primary export dependence, absorptive capacity, business regulation, and labor regulation.

The ratio of primary exports to GDP $\left(P R_{i}\right)$ is employed as measure of primary export dependence. The secondary school enrolment rate $\left(\mathrm{SCHOOL}_{i}\right)$ is taken as a proxy for absorptive capacity, and business regulation is represented by the ease-ofdoing-business index $\left(E A S E_{i}\right)$. The higher this index, the more conducive the regulatory environment is to the operation of business. Labor market regulation is measured by the rigidity of employment index $\left(R I G_{i}\right)$. A higher rigidity of employment index indicates more rigid labor regulations.

\footnotetext{
9 The coefficients are insignificant for Burkina Faso, Cameroon, Chile, Colombia, Egypt, El Salvador, Guatemala, Honduras, India, Senegal, Swaziland, Tunisia, and Uruguay.
} 
All data are from the World Development Indicators (2008) and are averaged over the period from 1971 to 2005 . An exception is the ease-of-doing-business index for which data before 2005 are not available, so that we are constrained to use values for that single year. Moreover, we do not have complete data on all variables for all countries, forcing us to exclude Gambia, Guinea-Bissau, and Swaziland from the sample.

To examine the relationship between the long-run impact of exports and the four variables, we regress $\hat{c}_{2 i}$ on $P R_{i}, S C H O O L_{i}, E A S E_{i}$, and $R I G_{i}$ (and an intercept). Since it is well known that an estimated dependent variable may introduce heteroskedasticity into the regressions (Saxonhouse 1976), we use White's heteroskedasticity-consistent standard errors to compute the $t$-statistics. The results of this regression are reported in column 1 of Table 8 .

\section{- Table 8 about here -}

Since the diagnostic tests suggest that obvious nonlinearity and misspecification are absent, and that the residuals show no signs of nonnormality or heteroscedasticity, the following inferences can be drawn from the results: the long-run effect of exports on non-export GDP is significantly negatively associated with primary export dependence, business regulation, and labor regulation. ${ }^{10}$ In contrast, there is no statistically significant association between the long-run effect of exports and absorptive capacity, measured by the secondary school enrolment rate. As can be seen from column 2 , this result does not change when alternative measures for absorptive capacity are used. This column shows the regression results when the secondary school enrolment rate is replaced 
by per capita PPP GDP. As in column 2, primary export dependence, business regulation and labor regulation are statistically significant (with the correct signs), while the coefficient of absorptive capacity, measured by per capita PPP GDP, is not.

Indeed, a potential problem with this analysis is that the estimated coefficients on $\ln \left(X_{i t}\right)$ are not statistically significant for all countries. However, as columns 3 and 4 show, the results do not change qualitatively if we set the long-run effect of exports on non-export GDP equal to zero for the countries with insignificant coefficients. Without question, our sample is too small to draw definite conclusions about systematic variations in the long-run effect of exports across countries. In addition, the adjusted $R^{2} \mathrm{~s}$ indicate that only about 10 percent of the variation in the long-run effect of exports on non-export GDP is explained by the variables in the models, implying that the estimated regressions do not fit the data very well. Nevertheless, the results seem to suggest that cross-country differences in the long-run effect of exports on non-export GDP can be at least partly explained by cross-country differences in primary export dependence, business regulation, and labor regulation.

\section{Conclusions}

This paper challenges the conventional view that exports generally contribute more to GDP growth than the mere change in export volume, as the export-led growth hypothesis predicts. We first examined the nature of the growth effect of exports by applying panel cointegration methods to a production function model with non-export GDP as the dependent variable. Our results, based on data from 1971 to 2005 for 45 developing

\footnotetext{
${ }^{10}$ Note that the sign of the coefficient on $E A S E_{i}$ is positive, since a higher value of the ease of doing business index indicates a lower level of business regulation.
} 
countries, show that the short-run relationship between exports and non-export GDP is positive. In the long-run, however, an increase in exports leads to a reduction in nonexport GDP in developing countries, on average. This effect is robust to alternative estimation techniques, outliers, sample selection, and different subperiods. Nevertheless, there are large differences in the long-run effect of exports on non-export GDP across countries. More specifically, we found that an increase in exports is associated with a long-run decrease in non-export GDP in 69 percent of the countries; in 31 percent of the cases, an increase in exports is associated with a long-run increase in non-export GDP.

Next, we examined whether the observed cross-country differences in the longrun effect of exports are linked to country-specific factors, such as the level of primary export dependence, business regulation, labor regulation, and the capacity of a country to absorb knowledge. Our results suggest that the long-run effect of exports on nonexport GDP is significantly negatively associated with primary export dependence, business regulation, and labor regulation, whereas there is no statistically significant association between the growth effect of exports and absorptive capacity. All in all, it can be (cautiously) concluded that economic reforms aimed at (i) removing primary export dependence by diversifying the economy, (ii) minimizing the regulatory burden on business, and (iii) increasing labor market flexibility can not only protect developing countries from the potential negative consequences of increased exports but also induce export-led growth in the long run. 


\section{References}

Abu-Quarn AS, Abu-Bader S (2004) The validity of the ELG hypothesis in the MENA region: cointegration and error correction model analysis. Appl Econ 36: 168595.

Ahmad J., Harnhirun S. (1995) Unit roots and cointegration in estimating causality between exports and economic growth: empirical evidence from the ASEAN countries. Econ Letters 49: 329-334.

Al-Yousif YK (1997) Exports and economic growth: some empirical evidence from the Arab Gulf Countries. Appl Econ 29: 693-97.

Bahmani-Oskooee M, Mohtadi H, Shabsigh G (1991) Exports, growth and causality: a re-examination. J Devel Econ 36: 405-415.

Bahmani-Oskooee M, Alse J (1993) Export growth and economic growth: an application of cointegration and error correction modelling. J Developing Areas 27: $535-542$.

Bahmani-Oskooee M, Economidou C, Goswami GG (2005) Export-led growth hypothesis revisited: a panel cointegration approach. Sci J Admin Dev 3: 40-55.

Bahmani-Oskooee M, Oyolola M (2007) Export growth and output growth: an application of bounds testing approach. J Econ Finance 31: 1-11.

Bahmani-Oskooee M, Economidou C (2009). Export-led growth vs. growth-led exports: LDCs experience. J Developing Areas 42: 179-209

Bai J, Ng S (2002) Determining the number of factors in approximate factor models. Econometrica 70: 191-221. 
Bai J, Ng S (2004) A PANIC attack on unit roots and cointegration. Econometrica 72: 1127-1177.

Balassa B, (1978) Exports and economic growth: further evidence. J Devel Econ 5: 181189.

Banerjee A, Marcellino M, Osbat C (2004) Some cautions on the use of panel methods for integrated series of macroeconomic data. Econometrics J 7: 322-340.

Banerjee A, Russell B (2005) Inflation and measures of the markup. J Macroecon 27: 289-306.

Breitung J (2005) A parametric approach to the estimation of cointegrating vectors in panel data. Econometric Rev. 24: 151-173.

Campbell JY, Perron P (1991): Pitfalls and opportunities: What macroeconomists should know about unit roots, in Blanchard OJ, Fischer S (eds.): NBER macroeconomics annual, 1991, MIT Press, Cambridge Massachusetts, 141-201.

Chow PCY (1987) Causality between export growth and industrial development: Empirical evidence from NICs. J Devel Econ 26: 55-63.

Chuang Y-C (1998) Learning by doing, the technology gap, and growth. Int Econ Rev 39: 697-721.

Dawe D (1996) A new look at the effects of export instability on investment and growth. World Devel 24: 1905-1914.

DeJong DN, Whiteman CH (1991) The case for trend-stationarity is stronger than we thought. J. Appl. Econometrics 6: 413-421. 
Dodaro S (1993) Exports and growth: a reconsideration of causality. J Developing Areas 27: $227-244$.

Edwards S (1988) Terms of trade, tariffs, and labor-market adjustment in developing countries. World Bank Econ Rev 2: 165-185.

Edwards S (1993) Openness, trade liberalisation, and growth in developing countries. J Econ Lit 31: 1358-1393.

Feder G (1983) On exports and economic growth. J Devel Econ 12: 59-73.

Gengenbach C, Palm FC, Urbain J-M (2006) Cointegration testing in panels with common factors, Oxford Bull Econ Statist 68, Supplement: 683-719.

Giles JA, Williams CL (2000) Export-led growth: a survey of the empirical literature and some non-causality results. Part 1. J Int Trade Econ Devel 9: 261-37.

Granger CWJ (1969) Investigating causal relationships by econometric models: crossspectral methods. Econometrica 37: 424-438.

Granger CWJ (1988) Some recent developments in a concept of causality. J Econometrics 39: 199-211.

Greenaway D, Sapsford D (1994) What does liberalisation do for exports and growth? Rev World Econ 130: 152-174.

Grossman GM, Helpman E (1991) Innovation and growth in the global economy. MIT Press, Cambridge, Mass.

Heller P, Porter R (1978). Exports and growth: an empirical reinvestigation. J Devel Econ 5: 191-193. 
Helpman E, Krugman P (1985). Market structure and foreign trade. MIT Press, Cambridge, Mass.

Herzer D (2007). How does trade composition affect productivity? Evidence for Chile. Appl Econ Letters 14: 909-912.

Herzer D (2008). The long-run relationship between outward FDI and domestic output: evidence from panel data. Econ Letters 100: 146-149.

Herzer D (2010). A further examination of the export-led growth hypothesis. Discussion Paper No. 200, Ibero-America Institute for Economic Research (IAI), Goettingen.

Hsiao MCW (1987) Tests of causality and exogeneity between exports and economic growth: the case of Asian NICs. J Econ Devel 12: 149-159.

Im KS, Pesaran MH, Shin Y (2003) Testing for unit roots in heterogeneous panels. J Econometrics 115: 53-74.

Johansen S (1995) Likelihood based inference in cointegrated vector autoregressive models, Oxford University Press, Oxford.

Jun S (2007) Bi-directional relationships between exports and growth: a panel cointegration analysis. J Econ Res 12: 133-171.

Jung WS, Marshall PJ (1985) Exports, growth and causality in developing countries. J Devel Econ 18: 1-12.

Kao C, Chiang M (2000) On the estimation and inference of a cointegrated regression in panel data. Advances in Econometrics 15: 179-222. 
Kapetanios G, Pesaran MH, Yamagata T (2011) Panels with nonstationary multifactor error structures. J Econometrics 160: 326-348.

Kavoussi RM (1984) Export expansion and economic growth: further empirical evidence. J Devel Econ 14: 241-250.

Kunst RM, Marin D (1989) On exports and productivity: a causal analysis. Rev Econ Statist 71: 699-703.

Levin A, Lin C-F, Chu C-SJ (2002) Unit root test in panel data: asymptotic and finitesample properties. J Econometrics 108:1-24.

Leybourne SJ (1995) Testing for unit roots using forward and reverse Dickey-Fuller regressions. Oxford Bull Econ Statist 57: 559-571.

Love J Chandra R (2004) Testing export-led growth in India, Pakistan and Sri Lanka using a multivariate framework. Manchester Sch 72: 483-96.

Love J (1994) Engines of growth: the export and government sectors. World Economy 17: $203-218$.

McNab RM, Moore RE (1998) Trade policy, export expansion, human capital and growth. J Int Trade Econ Devel 7: 237-256.

Michaely M (1977) Exports and growth: an empirical investigation. J Devel Econ 4: 4953.

Parida PC, Sahoo P (2007) Export-led growth in South Asia: a panel cointegration analysis. Int Econ J 21: 155-175.

Pedroni, P (1999) Critical values for cointegration tests in heterogeneous panels with multiple regressors. Oxford Bull Econ Statist 61: 653-670. 
Pedroni P (2000) Fully modified OLS for heterogeneous cointegrated panels. Advances in Econometrics 15: 93-130.

Pedroni P (2001) Purchasing power parity tests in cointegrated panels. Rev Econ Statist 83: 727-731.

Pedroni P (2004) Panel cointegration: asymptotic and finite sample properties of pooled time series tests with an application to the PPP hypothesis. Econometric Theory 20: 597-625.

Pesaran MH (2006) Estimation and inference in large heterogeneous panels with a multifactor error structure. Econometrica 74: 967-1012.

Phillips PCB, Hansen BE (1990) Statistical inference in instrumental variables regression with I(1) processes. Rev Econ Stud 57: 99-125.

Ram R (1985) Exports and economic growth: some additional evidence. Econ Devel Cult Change 33: 415-425.

Ram R (1987) Exports and economic growth in developing countries: evidence from time-series and cross-section data. Econ Devel Cult Change 36: 51-72.

Reppas PA, Christopoulos DK (2005) The export-output growth nexus: evidence from African and Asian countries. J Pol Modeling 27: 929-940.

Riezman RG, Summers PM, Whiteman CH (1996) The engine of growth or its handmaiden? A time series assessment of export-led growth. Empirical Econ 21: 77113.

Sachs J, Warner A (1995) Natural resource abundance and economic growth. NBER Working Paper No. 5398. 
Salvatore D, Hatcher T (1991) Inward and outward oriented trade strategies. J Devel Stud 27: 7-25.

Saxonhouse G (1976) Estimated parameters as dependent variables. Amer Econ Rev 66: $178-183$.

Sharma SC, Dhakal D (1994) Causal analysis between exports and economic growth in developing countries. Appl Econ 26: 1145-1157.

Siliverstovs B, Herzer D (2007) Manufacturing exports, mining exports, and growth: cointegration and causality analysis for Chile (1960-2001). Appl Econ 39: 153167.

Sims CA (1972) Money, income, and causality. Amer Econ Rev 62: 540-552.

Stock JH, Watson MW (1993) A simple estimator of cointegrating vectors in higherorder integrated systems. Econometrica 61: 783-820.

Toda HY. Phillips PCB (1993) Vector autoregressions and causality. Econometrica 61: 1367-1393.

Tyler W (1981) Growth and export expansion in developing countries: some empirical evidence. J Devel Econ 9: 121-130.

Van den Berg H, Schmidt JR (1994) Foreign trade and economic growth: time series evidence from Latin America. J Int Trade Econ Devel 3: 249-268.

World Bank (2009) Doing business 2009. Comparing regulation in 181 economies. Washington, DC: The World Bank. 
Table 1 Unit root tests

\begin{tabular}{lcc}
\hline Variables & Common components & Idiosyncratic components \\
\hline Non-export GDP & -2.923 & $-3.633 * *$ \\
Capital & -3.356 & $-5.303 * *$ \\
Exports & -1.800 & $-4.942 * *$ \\
\hline
\end{tabular}

The optimal lag length was determined using the general-to-simple approach suggested by Campbell and Perron (1991). We employed the ADF test (with a constant and a linear time trend) for the common components and the panel unit root test of Im, Pesaran, and Shin (2003) (IPS) for the idiosyncratic components. ** indicate a rejection of the unit root null hypothesis at the $1 \%$ level.

Table 2 Cointegration of common components

\begin{tabular}{lccc}
\hline Rank null hypothesis & $r \leq 0$ & $r \leq 1$ & $r \leq 2$ \\
Johansen (1995) trace statistics & $34.85^{*}$ & 9.90 & 0.33 \\
\hline
\end{tabular}

* indicates a rejection of the null hypothesis of no cointegration at the $5 \%$ level. The number of lags was determined by the Schwarz criterion. To correct for finite sample bias, the trace statistic was multiplied by $(T-p k) / T$, where $T$ is the number of the observations, $p$ the number of the variables, and $k$ the lag order (Reimers 1992). Critical values are from MacKinnon et al. (1999). 
Table 3 Cointegration of idiosyncratic components

\begin{tabular}{lcc}
\hline & $\begin{array}{c}\text { Panel cointegration } \\
\text { statistics }\end{array}$ & Group mean panel cointegration \\
\hline Variance ratio & $2.042^{*}$ & \\
PP rho-statistics & $-4.410^{* *}$ & -0.617 \\
PP $t$-statistics & $-5.607^{* *}$ & $-3.961^{* *}$ \\
ADF $t$-statistics & $-5.786^{* *}$ & $-4.354^{* *}$ \\
\hline
\end{tabular}

** $\left(^{*}\right)$ indicate a rejection of the null hypothesis of no cointegration at the $1 \%(5 \%)$ level. The statistics are the standard residual-based panel and group test statistics suggested by Pedroni $(1999,2004)$. All test statistics are asymptotically normally distributed. The variance ratio test is right-sided, while the other tests are left-sided. The maximum truncation lags were set to 4 and determined using data dependent criteria.

Table 4 Estimates of the long-run effects on non-export GDP

\begin{tabular}{lccc}
\hline & $\ln \left(K_{i t}\right)$ & $\ln \left(X_{i t}\right)$ & Leads and lags \\
\hline (1) Group-mean DOLS & $0.279 * *(35.25)$ & $-0.152 * *(-11.69)$ & 1 \\
(2) Group-mean DOLS & $0.279 * *(29.97)$ & $-0.102 * *(-9.77)$ & 2 \\
(3) Within-dimension DOLS & $0.264 * *(19.99)$ & $-0.167 * *(-9.85)$ & 1 \\
(4) CCE mean group & $0.224 * *(33.48)$ & $-0.229 * *(-16.59)$ \\
\end{tabular}

Dependent variable $\ln \left(N_{i t}\right) .{ }^{* *}$ indicate significance at the $1 \%$ level. $t$-statistics in parentheses. Group mean DOLS estimator (Pedroni, 2001), Within dimension DOLS estimator (Kao and Chiang, 2000), CCE mean group estimator (Pesaran, 2006) 
Table 5 DOLS estimation with regional country groups excluded from the sample

\begin{tabular}{lccc}
\hline & $\ln \left(K_{i t}\right)$ & $\ln \left(X_{i t}\right)$ & Countries \\
\hline Excluding North Africa & $0.280^{* *}(31.81)$ & $-0.136^{* *}(-11.09)$ & 41 \\
Excluding sub-Saharan & & & \\
Africa & $0.337^{* *}(36.12)$ & $-0.123^{* *}(-8.07)$ & 26 \\
Excluding South America & $0.255^{* *}(29.96)$ & $-0.185^{* *}(-12.44)$ & 36 \\
Excluding Central Amer- & & & 39 \\
ica and the Caribbean & $0.296^{* *}(33.43)$ & $-0.178^{* *}(-11.80)$ & 42 \\
Excluding East Asia & $0.252^{* *}(29.25)$ & $-0.125^{* *}(-9.17)$ & 41 \\
Excluding South Asia & $0.273^{* *}(33.79)$ & $-0.161^{* *}(11.26)$ & \\
\hline
\end{tabular}

** indicate significance at the $1 \%$ level. $t$-statistics in parentheses. The DOLS regressions were estimated with one lead and one lag. The countries included in each region are: North Africa: Algeria, Egypt, Morocco, Tunisia; sub-Saharan Africa: Benin, Burkina Faso, Cameroon, Côte d'Ivoire, Gambia, Ghana, Guinea-Bissau, Kenya, Lesotho, Madagascar, Malawi, Mali, Rwanda, Senegal, South Africa, Sudan, Swaziland, Togo, Zambia; South America: Argentina, Bolivia, Brazil, Chile, Colombia, Ecuador, Paraguay, Peru, Uruguay; Central America and the Caribbean: Costa Rica, Dominican Republic, El Salvador, Guatemala, Honduras, Mexico; East Asia: Indonesia, Thailand; South Korea; South Asia: Bangladesh, India, Iran, Pakistan. 
Table 6 DOLS estimation for different subperiods

\begin{tabular}{lcl}
\hline & $\ln \left(K_{i t}\right)$ & \multicolumn{1}{l}{$\ln \left(X_{i t}\right)$} \\
\hline $1971-1987$ & $0.287^{* *}(33.25)$ & $-0.117(-6.36)^{* *}$ \\
$1988-2004$ & $0.295 * *(34.11)$ & $-0.164 * *(-12.98)$ \\
\hline
\end{tabular}

** indicate significance at the $1 \%$ level. $t$-statistics in parentheses. The DOLS regressions were estimated with one lead and one lag.

Table 7 Vector error-correction model, long-run causality and short-run dynamics

\begin{tabular}{lccc}
\hline Regressors & Dependent variable & Dependent variable & Dependent variable \\
& $\Delta \ln \left(N_{i t}\right)$ & $\Delta \ln \left(K_{i t}\right)$ & $\Delta \ln \left(X_{i t}\right)$ \\
\hline$e c_{i t-1}$ & $-0.402 * *(-16.09)$ & $-0.088(-1.34)$ & $0.055(1.33)$ \\
\hline$\Delta \ln \left(N_{i t-1}\right)$ & $0.127 * *(4.96)$ & $0.222^{* *}(3.10)$ & $0.040 *(2.28)$ \\
$\Delta \ln \left(N_{i t-2}\right)$ & $-0.099 *(-4.10)$ & - & - \\
$\Delta \ln \left(K_{i t-1}\right)$ & - & $-0.075^{*}(-2.45)$ & $0.049 * *(2.61)$ \\
$\Delta \ln \left(K_{i t-2}\right)$ & - & $-0.104 * *(-3.91)$ & $0.060 * *(3.31)$ \\
$\Delta \ln \left(X_{i t-1}\right)$ & $0.058^{* *}(3.66)$ & $0.189 * *(4.71)$ & $-0.068^{*}(-2.61)$ \\
$\Delta \ln \left(X_{i t-2}\right)$ & - & - & $-0.078^{* *}(-3.00)$ \\
& & - &
\end{tabular}

** $\left(^{*}\right)$ indicate significance at the $1 \%(5 \%)$ level. $t$-statistics in parentheses. The maximum number of lags was determined by the Schwarz criterion. Insignificant short-run dynamics were eliminated successively according to the lowest $t$-values and hence are not reported here. 
Table 8 Long-run export effects and country specific factors

\begin{tabular}{lcccc}
\hline Regressors & $(1)$ & $(2)$ & $(3)$ & $(1)$ \\
\hline$P R_{i}$ & $-0.014 *(-2.25)$ & $-0.014 *(-2.13)$ & $-0.015^{* *}(-4.23)$ & $-0.015^{* *}(-4.14)$ \\
& & & $0.002(1.52)$ & \\
SCHOOL $_{i}$ & $0.003(1.49)$ & & $0.00002(1.58)$ \\
GDPPC $_{i}$ & & $0.00002(1.10)$ & & \\
& & & & \\
EASE $_{i}$ & $0.004 *(2.16)$ & $0.004 *(2.05)$ & $0.003 *(2.21)$ & $0.003 *(2.16)$ \\
RIG $_{i}$ & $-0.011 *(-2.02)$ & $-0.012 *(-2.22)$ & $-0.007+(-1.71)$ & $-0.007 *(-2.15)$
\end{tabular}

Diagnostics

$\begin{array}{lcccc}\text { Adj. } R^{2} & 0.11 & 0.10 & 0.18 & 0.19 \\ \text { RESET } & 0.023(0.88) & 0.637(0.43) & 0.033(0.86) & 0.015(0.90) \\ \text { JB } & 2.833(0.24) & 3.233(0.20) & 0.574(0.75) & 0.962(0.20) \\ \text { Included ob- } & 42 & 42 & 42 & 42 \\ \text { servations } & & & & \end{array}$

$* *\left(^{*}\right)[+]$ indicates significance at the $1 \%(5 \%)[10 \%]$ level. Reported $t$-statistics (in parentheses) are based on White's heteroskedasticity-consistent standard errors; the numbers in parentheses behind the diagnostic test statistics are the corresponding $p$ values: RESET is the usual test for general nonlinearity and misspecification and $J B$ is the Jarque-Bera test for normality. The dependent variable in the regressions in columns 1 and 2 is the estimated effect of exports on non-export GDP. In columns 4 and 5, the long-run effect of exports on non-export GDP was set equal to zero for the countries with insignificant coefficients. 
Fig 1. Estimated export elasticity with single country excluded from the sample

Coefficients on $\ln \left(X_{i t}\right)$ $t$-statistics of the coefficients
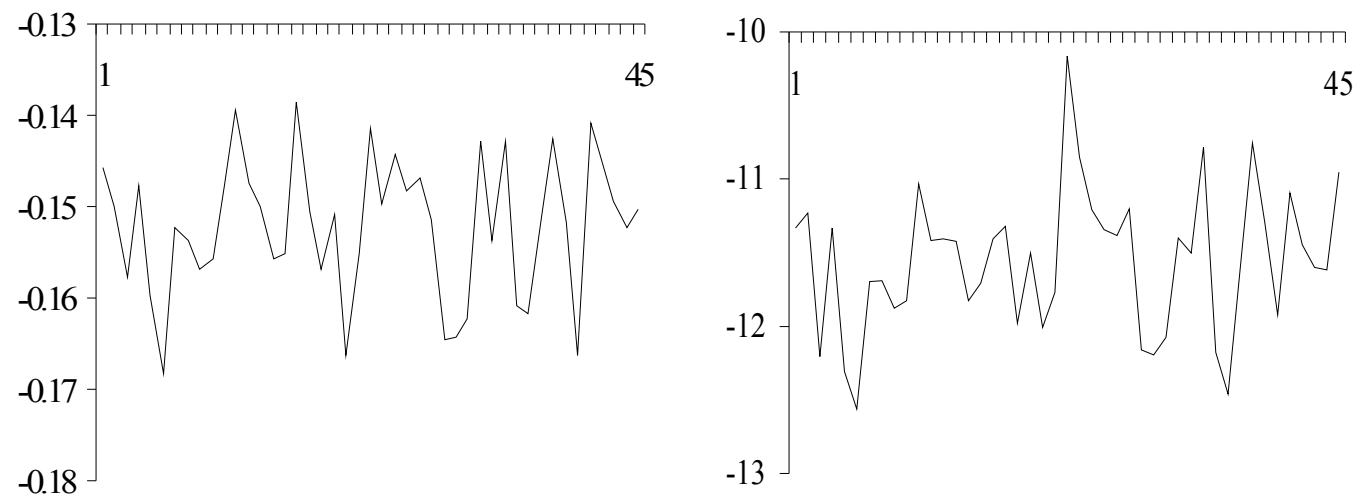

Note: The figures shows the coefficients on $\ln \left(X_{i t}\right)$ and their $t$-statistics of the sequentially estimated regressions when one country is excluded at a time. Each tick marks the country omitted from the regression.

Fig. 2. Country individual DOLS estimates of the long-run impact of exports on nonexport GDP

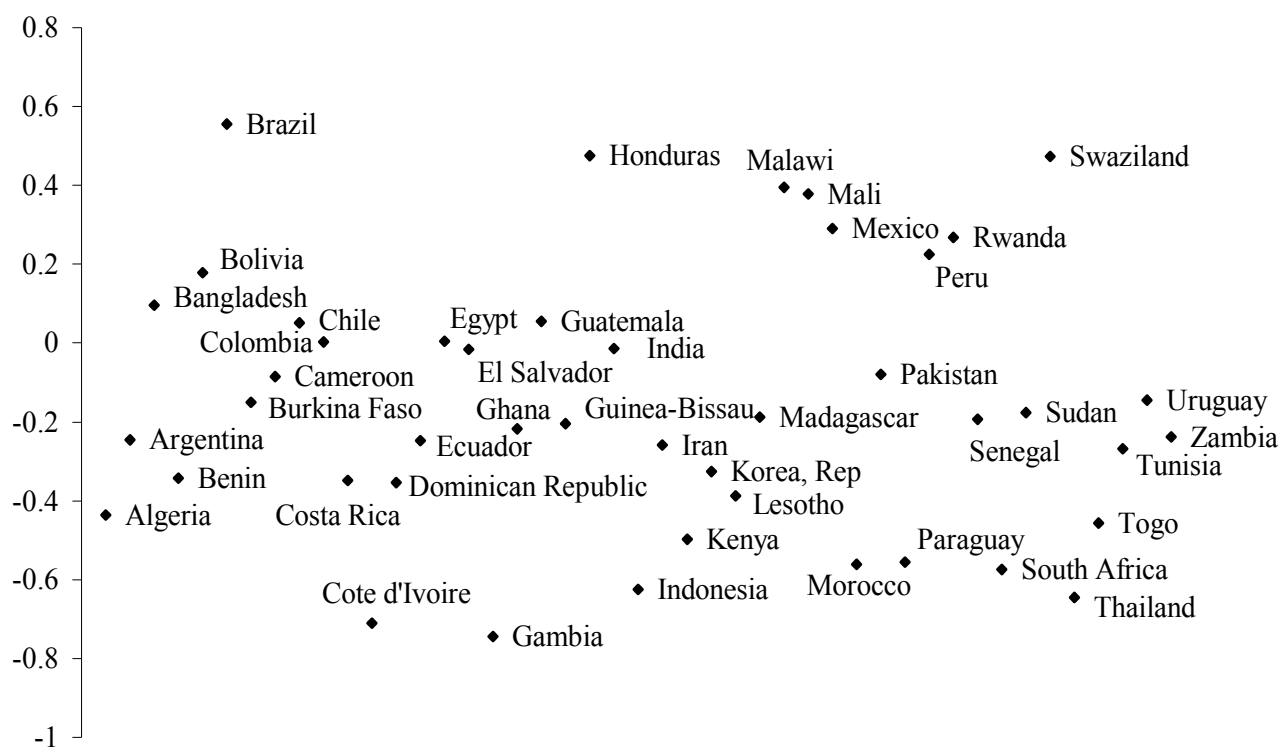

